Brit. J. Ophthal. (1964) 48, 480.

\title{
CLINICAL OBSERVATIONS ON THE USE OF PHOSPHOLINE IODIDE IN GLAUCOMA*
}

BY

\author{
J. ROMANO AND H. JACKSON \\ Neasden Eye Unit
}

THE present study is an account of our experience of cases treated by Echothiophate iodide (gutt. phospholine iodide, P.I.), as well as some observations on the patients. The nature, properties, and action of this drug have been discussed in recent papers by Lloyd (1963), Holmberg (1962), and Giardini and Paliaga (1959) in Europe, and in the original and comprehensive papers originating from the U.S.A. (Leopold, Gold, and Gold, 1957; Mamo and Leopold, 1958; Becker, Pyle, and Drews, 1959; Becker and Gage, 1960; Schaumann and Job, 1958; Gray and Robinson, 1960, etc.) and from Canada (Drance, 1959, 1960; Drance and Carr, 1960).

\section{Material}

The study covers the follow-up of 36 eyes in 21 patients. These included chronic simple glaucoma-23 eyes; glaucoma capsulo-cuticulare-4 eyes, plus 1 probable case; pigmentary glaucoma- 2 eyes; thrombotic glaucoma- 1 eye plus 2 possible cases; mixed glaucoma2 eyes; and chronic closed-angle glaucoma, with deep anterior chamber-1 eye.

It may be noted that at first all cases with open angles were considered suitable for trial on phospholine iodide. However, for reasons to be given below, in the later selection of cases only those with angles of wide or, at least, intermediate depth were considered.

\section{Method}

The original assessments and investigations were carried out when the subjects were inpatients; phasing and tonography were carried out while they were on the treatment previously employed, increased when necessary to Pilocarpine drops 2-4 per cent. and eserine 0.25 per cent. up to four times a day, with or without small doses of Diamox. Scotometry, and, in particular, careful gonioscopic examination were performed to limit the trial to cases of definite open-angle glaucoma.

If control was considered to be inadequate, treatment with phospholine iodide (P.I.) was instituted.

After the patients had been discharged, periodical control was carried out initially in the Out-patients Department, and when doubt arose over the efficacy of control, they were readmitted to hospital. Follow-up was carried on for periods of up to 14 months or more from the time when P.I. therapy was instituted.

\section{Criteria of Control}

The cases were divided into three groups:

(1) Controlled: Tensions below or at $25 \mathrm{~mm}$. Hg (Schiötz). 
(2) Imperfectly Controlled: Tensions above 25 but below $30 \mathrm{~mm}$. $\mathrm{Hg}$, with no progression of field loss or disc changes.

(3) Failures: Tension consistently at or above $30 \mathrm{~mm} . \mathrm{Hg}$, with evidence of field loss, and raised $\mathrm{Po} / \mathrm{C}$.

A figure was thus chosen that is intermediate between that selected by Leopold and others (1957) at $30 \mathrm{~mm}$. Hg (Schiötz), and that of Lawlor and Lee (1960) at $22 \mathrm{~mm}$. Hg (the figure of Leopold and others is presumably based on the "old calibration," and so represents 27 to $28 \mathrm{~mm}$. by the modern standard).

\section{Results}

\section{(1) Control of Tension}

$\left.\begin{array}{lrl}\text { Controlled for } 14 \text { months or more } & 14 \text { eyes } & (38 \cdot 88 \text { per cent. }) \\ \text { Imperfectly controlled } & 9 \text { eyes } & (25 \cdot 0 \text { per cent. }) \\ \text { Failures } & 13 \text { eyes } & (36 \cdot 11 \text { per cent. })\end{array}\right\}$ Total 36

If we compare this with the results taken 6 months after starting treatment, the picture is very different:

$\left.\begin{array}{lrr}\text { Controlled } & 25 \text { eyes } & (72 \cdot 2 \text { per cent. }) \\ \text { Imperfectly controlled } & 5 \text { eyes } \\ \text { Failures } & 6 \text { eyes }\end{array}\right\}$ Total 36

Results related to type of glaucoma:

Chronic Simple Glaucoma (considered after 14 months or more)

$\left.\begin{array}{lrl}\text { Controlled } & 11 \text { eyes } & (47 \cdot 8 \text { per cent. }) \\ \text { Imperfectly controlled } & 7 \text { eyes } & (30 \cdot 4 \text { per cent. }) \\ \text { Failures } & 5 \text { eyes } & (21 \text { per cent. })\end{array}\right\}$ Total 23

Glaucoma capsulare: $\left\{\begin{array}{l}2 \text { failures } \\ 3 \text { incompletely controlled }\end{array}\right.$

Pigmentary glaucoma: both failed

Chronic closed-angle: acute attack during initial trial.

The "failed" cases have all been operated upon, and, increasingly, more of the "imperfectly controlled" cases. In the latter group, increasingly, adjuvant methods, such as carbonic anhydrase inhibitors and epinephrine drops 1 per cent., are being used, especially when, as is often the case, advanced age or other contraindications exist to operative treatment.

\section{(2) Form of Anterior Chamber}

In the phakic cases, there was a frequent appearance of iris bombe in eyes in which the iris had previously been flat. This was accompanied by the impression of an apparent decrease in depth of the anterior chamber in most cases, which occurred after a variable period of treatment with P.I., commonly a few weeks.

Of 32 phakic eyes, twenty showed this change after 6 to 14 months (62.5 per cent.), and the other twelve conserved the form of their anterior chamber. 
It is interesting that, of the twenty eyes showing an iris bombe appearance, seven were controlled ( 35 per cent.), nine were imperfectly controlled ( 45 per cent.), and four were not controlled ( 20 per cent.).

Of the twelve eyes in which the appearance of the anterior chamber was unchanged (if we exclude the two eyes of Case 14 in which the trial was interrupted because of sensitivity to the drug), eight out of ten eyes were controlled and two were failures. Therefore, 65 per cent. of eyes in which the anterior chamber had assumed a bombé appearance were controlled imperfectly or not at all, a percentage less favourable than that found in those with no bowing forwards of the iris.

\section{(3) Tonography}

As a rule, the facility of outflow and outflow co-efficient $(\mathrm{Po} / \mathrm{C})$, as might be expected, improved hand-in-hand with the control of tension. However, exceptions were found in which the tension was (more or less) controlled, but tonographic studies revealed little or no improvement in outflow. These cases were mostly to be found in the "imperfectly controlled" group, and figures as low as $\mathrm{C}=0.09$ and a $\mathrm{Po} / \mathrm{C}$ as high as 470 were recorded in the presence of tensions around $25 \mathrm{~mm}$. $\mathrm{Hg}$. A similar finding was reported in four cases by Drance and Carr (1960).

\section{(1) Control of Tension}

\section{Discussion}

This was achieved satisfactorily, and usually rapidly, in patients in whom all other medical treatment failed, on a dosage of P.I. as low as 0.12 per cent. once a day, but usually 0.25 per cent. once a day. At the end of the period of control and adjustment in hospital, fifteen patients showed a fall in the mean value of the tension range of $15-20 \mathrm{~mm}$. $\mathrm{Hg}$, nine eyes a fall of 10 to $12 \mathrm{~mm} . \mathrm{Hg}$, and other cases showed a small fall (Table).

However, after an initial period of variable length ( 3 to 6 months or longer), the tension rose again in many cases, often to levels precluding further reliance on the drug and necessitating surgical intervention.

The difference between the figures reported after 6 months of trial and those after 14 months agrees with that of Holmberg (1962), whose series includes fourteen eyes controlled for 3 months but not for 6 months, and also with the observation of Lloyd (1963), that "eventual failures" are observed if the follow-up period is sufficiently long.

\section{(2) Form of Anterior Chamber}

The explanation of the appearance of iris bombe is a probably simple one. Ciliary spasm increases the curvature of the lens, and tends to draw the ciliary body forwards, with or without some degree of relative pupillary block (Barkan, 1954; Swan, 1959; Grant, 1962). Congestion of the ciliary body may occur, increasing its volume, and this "will obviously result in a slight decrease in the chamber angle depth" (Sugar, 1951).

The reason why it has not been previously observed to such an extent is probably that powerful cholinesterase inhibitors have not in the past been used on phakic eyes for such long periods. 
TABLE

RESULTS IN 21 CASES

\begin{tabular}{|c|c|c|c|c|c|c|}
\hline Case & Diagnosis & $\begin{array}{c}\text { Previous } \\
\text { Treatment }\end{array}$ & $\begin{array}{c}\text { Previous } \\
\text { Tension-Range }\end{array}$ & $\begin{array}{c}\text { Guttae } \\
\text { Echothiophate }\end{array}$ & $\begin{array}{l}\text { Tension-Range } \\
\text { on Guttae } \\
\text { Echothiophate }\end{array}$ & Remarks \\
\hline $\begin{array}{l}\text { 1. R. eye } \\
\text { L. eye }\end{array}$ & $\begin{array}{l}\text { Chronic Simple } \\
\text { Glaucoma } \\
\text { (C.S.G.) } \\
\text { C.S.G. }\end{array}$ & $\begin{array}{l}\text { g. piloc. } 2 \% \\
\text { q.i.d. } \\
\text { g. piloc. } 2 \% \\
\text { q.i.d. }\end{array}$ & $\begin{array}{l}35-37 \mathrm{mms} \text {. } \\
27-30 \mathrm{mms} \text {. }\end{array}$ & $\begin{array}{l}0.25 \% \text { o.d. } \\
0.25 \% \text { o.d. }\end{array}$ & $\begin{array}{l}21-22 \mathrm{mms} . \\
18 \mathrm{mms} .\end{array}$ & Controlled \\
\hline 2. R. eye & C.S.G. & $\begin{array}{l}\text { g. piloc. } 3 \% \text { and } \\
\text { eserine } 1 \% \% \\
\text { t.i.d. }\end{array}$ & 32-37 mms. & $\begin{array}{l}0.25 \% \text { b.d. plus } \\
\text { Diamox }\end{array}$ & $18-26 \mathrm{mms}$. & $\begin{array}{l}\text { Controlled for } 6 \\
\text { months. Im- } \\
\text { perfectly controlled } \\
\text { after } 1 \text { year }\end{array}$ \\
\hline $\begin{array}{l}\text { 3. R. eye } \\
\text { L. eye }\end{array}$ & $\begin{array}{l}\text { C.S.G. } \\
\text { C.S.G. }\end{array}$ & $\begin{array}{l}\text { g. pilocl } 2 \% \\
\text { t.i.d. } \\
\text { g. piloc. } 2 \% \\
\text { t.i.d. }\end{array}$ & $\begin{array}{l}27-32 \mathrm{mms} \text {. } \\
37-43 \mathrm{mms} \text {. }\end{array}$ & $\begin{array}{l}0.25 \% \text { o.d. } \\
0.25 \% \text { o.d. }\end{array}$ & $\begin{array}{l}14-22 \mathrm{mms} \text {. } \\
18-21 \mathrm{mms} \text {. }\end{array}$ & \} $\begin{array}{c}\text { Controlled after } 14 \\
\text { months }\end{array}$ \\
\hline $\begin{array}{l}\text { 4. R. eye } \\
\text { L. eye }\end{array}$ & $\begin{array}{l}\text { C.S.G. } \\
\text { Probably Mixed } \\
\text { Glaucoma }\end{array}$ & & $\begin{array}{l}40 \mathrm{mms} \text {. } \\
31 \mathrm{mms} \text {. }\end{array}$ & $\begin{array}{l}0 \cdot 125 \% \text { o.d. } \\
0.125 \% \text { o.d. }\end{array}$ & $\begin{array}{l}\text { 18-24 mms. } \\
18-24 \mathrm{mms} \text {. }\end{array}$ & $\int_{\text {months }}^{\text {Controlled after } 14}$ \\
\hline 5. R. eye & $\begin{array}{l}\text { Aphakic Glau- } \\
\text { coma with } \\
\text { extensive P.A.S. }\end{array}$ & $\begin{array}{l}\text { Two Cyclo- } \\
\text { dialysis ops. \& } \\
\text { a Scheie's op. } \\
2 \% \text { piloc. b.d. } \\
\text { with diamox. }\end{array}$ & 33-35 mms. & $\begin{array}{l}0.25 \% \text { plus } 125 \\
\text { mg. Diamox } \\
\text { o.d. }\end{array}$ & $20 \mathrm{mms}$. & $\begin{array}{l}\text { Controlled for } 6 \\
\text { months. Un- } \\
\text { controlled after } 12 \\
\text { months }\end{array}$ \\
\hline $\begin{array}{l}\text { 6. R. eye } \\
\text { L. eye }\end{array}$ & $\begin{array}{l}\text { C.S.G. } \\
\text { C.S.G. }\end{array}$ & $\begin{array}{l}\text { g. piloc. } 3 \% \\
\text { t.i.d. } \\
\text { g. piloc. } 3 \% \\
\text { t.i.d. }\end{array}$ & $\begin{array}{l}17-32 \mathrm{mms} \text {. } \\
20-27 \mathrm{mms} \text {. }\end{array}$ & $\begin{array}{l}0.125 \% \text { o.d. } \\
0.125 \% \text { o.d. }\end{array}$ & $\begin{array}{l}16-22 \mathrm{mms} . \\
16-23 \mathrm{mms} \text {. }\end{array}$ & Controlled \\
\hline $\begin{array}{l}\text { 7. R. eye } \\
\text { L. eye }\end{array}$ & $\begin{array}{r}\text { Thrombotic } \\
\text { Glaucoma } \\
\text { C.S.G. }\end{array}$ & $\begin{array}{l}\text { g. piloc. } 3 \% \\
\text { t.i.d. plus } \\
\text { diamox } 250 \\
\text { mgs. b.d. } \\
\text { As above }\end{array}$ & $\begin{array}{l}\text { Around } 25 \mathrm{mms} \text {. } \\
\text { Around } 37 \mathrm{mms} \text {. }\end{array}$ & $\begin{array}{l}0.25 \% \text { b.d. } \\
0.25 \% \text { b.d. }\end{array}$ & $\begin{array}{l}\text { 18-26 mms. } \\
20-32 \text { mms. }\end{array}$ & $\begin{array}{l}\text { Controlled for } 1 \\
\text { month only } \\
\text { L. filtering } \\
\text { operation }\end{array}$ \\
\hline $\begin{array}{l}\text { 8. R. eye } \\
\text { L. eye }\end{array}$ & $\begin{array}{l}\text { C.S.G. } \\
\text { (thrombotic?) } \\
\text { C.S.G. } \\
\text { (thrombotic?) }\end{array}$ & $\begin{array}{l}\text { g. piloc. } 2 \% \\
\text { t.i.f. } \\
\text { g. piloc. } 2 \% \\
\text { t.i.d. }\end{array}$ & $\begin{array}{l}23-31 \mathrm{mms} \text {. } \\
26-40 \mathrm{mms} \text {. }\end{array}$ & $\begin{array}{l}0.25 \% \text { o.d. } \\
0.25 \% \text { o.d. }\end{array}$ & $\begin{array}{l}14-26 \mathrm{mms} \text {. } \\
12-22 \mathrm{mms} \text {. }\end{array}$ & $\left\{\begin{array}{l}\text { Controlled for } 9 \\
\text { months then im- } \\
\text { perfectly } \\
\text { controlled in spite } \\
\text { of increase in } \\
\text { dosage. }\end{array}\right.$ \\
\hline $\begin{array}{l}\text { 9. } R \text {. eye } \\
\text { L. eye }\end{array}$ & $\begin{array}{l}\text { Glaucoma } \\
\text { Capsulo- } \\
\text { cuticulare } \\
\text { As above }\end{array}$ & $\begin{array}{l}\text { g. piloc. } 2 \% \\
\text { t.i.d. } \\
\text { g. piloc. } 2 \% \\
\text { t.i.d. }\end{array}$ & $\begin{array}{l}26-50 \mathrm{mms} \text {. } \\
36-42 \mathrm{mms} \text {. }\end{array}$ & $\begin{array}{l}0.25 \% \text { b.d. plus } \\
\text { Diamox } 125 \\
\text { mg. b.d. } \\
\text { As above }\end{array}$ & $\begin{array}{l}\text { Around } 26 \mathrm{mms} \text {. } \\
22-24 \mathrm{mms} \text {. }\end{array}$ & $\left\{\begin{array}{l}\text { Imperfectly } \\
\text { controlled for } 6 \\
\text { months. Failure } \\
\text { after } 18 \text { months. } \\
\text { Bilateral filtering } \\
\text { operation. }\end{array}\right.$ \\
\hline $\begin{array}{l}\text { 10. R. eye } \\
\text { L. eye }\end{array}$ & $\begin{array}{l}\text { C.S.G. } \\
\text { C.S.G. }\end{array}$ & $\begin{array}{l}\text { g. piloc. } 2 \% \\
\text { plus eserine } \\
1 \% \text { plus } \\
\text { diainox t.i.d. } \\
\text { As above }\end{array}$ & $\begin{array}{l}\text { 40-50 mms. } \\
35-40 \mathrm{mms} \text {. }\end{array}$ & $0.25 \%$ o.d. & Around $22 \mathrm{mms}$. & $\left\{\begin{array}{l}\text { Controlled for } 2 \\
\text { months only then } \\
\text { imperfectly } \\
\text { controlled }\end{array}\right.$ \\
\hline $\begin{array}{l}\text { 11. R. eye } \\
\text { L. eye }\end{array}$ & $\begin{array}{l}\text { C.S.G. } \\
\text { C.S.G. }\end{array}$ & $\begin{array}{l}\text { g. piloc. } 2 \% \\
\text { t.i.d. } \\
\text { g. piloc. } 2 \% \\
\text { t.i.d. }\end{array}$ & $\begin{array}{l}17-31 \mathrm{mms} \text {. } \\
17-29 \mathrm{mms} \text {. }\end{array}$ & $\begin{array}{l}0.125 \% \text { o.d. } \\
0.125 \% \text { o.d. }\end{array}$ & $\begin{array}{l}\text { Around } 22 \mathrm{mms} \text {. } \\
\text { Around } 22 \mathrm{mms} \text {. }\end{array}$ & $\left\{\begin{array}{l}\text { Controlled for } 6 \\
\text { months, then } \\
\text { controlled after } \\
\text { increasing dosage }\end{array}\right.$ \\
\hline $\begin{array}{l}\text { 12. R. eye } \\
\text { L. eye }\end{array}$ & $\begin{array}{l}\text { C.S.G. } \\
\text { C.S.G. }\end{array}$ & $\begin{array}{l}\text { g. piloc. } 2 \% \text { b.d. } \\
\text { g. piloc. } 2 \% \text { b.d. }\end{array}$ & $\begin{array}{l}26-34 \mathrm{mms} \text {. } \\
26-37 \mathrm{mms} \text {. }\end{array}$ & $\begin{array}{l}0.125 \% \text { o.d. } \\
0.125 \% \text { o.d. }\end{array}$ & $\begin{array}{l}16-24 \mathrm{mms} \text {. } \\
16-22 \mathrm{mms} \text {. }\end{array}$ & Controlled \\
\hline $\begin{array}{l}\text { 13. R. eye } \\
\text { L. eye }\end{array}$ & $\begin{array}{l}\text { Glaucoma } \\
\text { Capsulo- } \\
\text { cuticulare } \\
\text { As above }\end{array}$ & $\begin{array}{l}\text { g. piloc. } 4 \% \\
\text { q.i.d. \& eserine } \\
\frac{1}{2} \% \text { b.d. } \\
\text { As above }\end{array}$ & $\begin{array}{l}22-30 \mathrm{mms} \text {. } \\
20-36 \mathrm{mms} \text {. }\end{array}$ & $0.25 \%$ b.d. & $\begin{array}{l}18-21 \mathrm{mms} \text {. } \\
18-21 \mathrm{mms} \text {. }\end{array}$ & Controlled \\
\hline $\begin{array}{r}\text { 14. R. eye } \\
\text { L. eye }\end{array}$ & $\begin{array}{l}\text { C.S.G. } \\
\text { C.S.G. }\end{array}$ & $\begin{array}{l}\text { g. piloc. } 2 \% \text { plus } \\
\text { eserine } \frac{1}{2} \% \text { b.d. } \\
\text { g. piloc. } 2 \% \\
\text { plus eserine } \\
\frac{1}{2} \% \text { b.d. }\end{array}$ & $\begin{array}{l}32-39 \mathrm{mms} \text {. } \\
26-40 \mathrm{mms} \text {. }\end{array}$ & $\begin{array}{l}\text { Sensitive to } \\
\text { phospholine } \\
\text { iodide } \\
\text { As above }\end{array}$ & & $\begin{array}{c}\text { Bilateral drainage } \\
\text { operation }\end{array}$ \\
\hline 15. L. eye & $\begin{array}{l}\text { C.S.G. } \\
\text { (?pseudo- } \\
\text { extoliation) }\end{array}$ & $\begin{array}{l}\text { g. eserine } \frac{1}{2} \% \\
\text { q.i.d. \& Diamox } \\
125 \text { mgs. b.d.s. }\end{array}$ & $18-26 \mathrm{mms}$. & $0.25 \%$ b.d. & $18-22 \mathrm{mms}$. & $\begin{array}{l}\text { Controlled for } 4 \\
\text { months then } \\
\text { uncontrolled. } \\
\text { Scheie's op. }\end{array}$ \\
\hline
\end{tabular}


RESULTS IN 21 CASES-(continued)

\begin{tabular}{|c|c|c|c|c|c|c|}
\hline Case & Diagnosis & $\begin{array}{c}\text { Previous } \\
\text { Treatment }\end{array}$ & $\begin{array}{c}\text { Previous } \\
\text { Tension-Range }\end{array}$ & $\begin{array}{c}\text { Guttae } \\
\text { Echothiophate }\end{array}$ & $\begin{array}{l}\text { Tension-Range } \\
\text { on Guttae } \\
\text { Echothiophate }\end{array}$ & Remarks \\
\hline $\begin{array}{l}\text { 16. R. eye } \\
\text { L. eye }\end{array}$ & $\begin{array}{l}\text { C.S.G. } \\
\text { C.S.G. } \\
\text { (Aphakic) }\end{array}$ & & & $0.25 \%$ b.d. & & $\left\{\begin{array}{l}\text { Imperfect control } \\
\text { for } 4 \text { months, } \\
\text { failure after } 6 \\
\text { months. R. } \\
\text { filtering operation }\end{array}\right.$ \\
\hline 17. L. eye & $\begin{array}{l}\text { Chronic Closed- } \\
\text { Angle } \\
\text { Glaucoma }\end{array}$ & g. piloc. $1 \%$ b.d. & $36-43 \mathrm{mms}$. & $0.125 \%$ o.d. & $\begin{array}{l}16-23 \text { for a few } \\
\text { days }\end{array}$ & $\begin{array}{l}\text { Acute attack during } \\
\text { initial trial. } \\
\text { Drainage operation. }\end{array}$ \\
\hline $\begin{array}{l}\text { 18. R. eye } \\
\text { L. eye }\end{array}$ & $\begin{array}{l}\text { C.S.G. } \\
\text { C.S.G. }\end{array}$ & $\begin{array}{l}\text { g. piloc. } 3 \% \\
\text { plus eserine } \\
1 \% \% \text { t.i.d. } \\
\text { As above }\end{array}$ & $\begin{array}{l}22-38 \mathrm{mms} \text {. } \\
22-24 \mathrm{mms} \text {. }\end{array}$ & $\begin{array}{l}0.25 \% \text { o.d. } \\
0.25 \% \text { o.d. }\end{array}$ & $\begin{array}{l}14-18 \mathrm{mms} \text {. } \\
18-24\end{array}$ & Controlled \\
\hline 19. R. eye & C.S.G. & $\begin{array}{l}\text { Three trephine } \\
\text { ops., one } \\
\text { iridencleisis, g. } \\
\text { piloc. } 2 \% \% \\
\text { eserine } 1 \% \% \\
\text { q.i.d. plus } \\
\text { Diamox. } \\
\text { Cataract } \\
\text { extraction }\end{array}$ & $26-40 \mathrm{mms}$ & $0 \cdot 125 \%$ b.d. & $18 \mathrm{mms}$. & Controlled \\
\hline $\begin{array}{l}\text { 20. R. eye } \\
\text { L. eye }\end{array}$ & $\begin{array}{l}\text { C.S.G. } \\
\text { (? Pigmentary } \\
\text { Glaucoma) } \\
\text { As above }\end{array}$ & $\begin{array}{l}\text { g. piloc. } 3 \% \text { b.d. } \\
\text { g. piloc. } 3 \% \text { b.d. }\end{array}$ & $\begin{array}{l}26-38 \mathrm{mms} \text {. } \\
22-26 \mathrm{mms} \text {. }\end{array}$ & $\begin{array}{l}0.25 \% \% \text { b.d. } \\
0.25 \% \% \text { b.d. }\end{array}$ & $\begin{array}{l}19-26 \mathrm{mms} \text {. } \\
17-26 \mathrm{mms} \text {. }\end{array}$ & $\left\{\begin{array}{l}\text { Controlled for } 6 \\
\text { months, then } \\
\text { failure both eyes. } \\
\text { Bilateral filtering } \\
\text { operation. }\end{array}\right.$ \\
\hline 21. L. eye & C.S.G. & $\begin{array}{l}\text { g. piloc. } 2 \% \\
\text { t.i.d. }\end{array}$ & 36-40 mms. & $0.25 \%$ o.d. & $18-22 \mathrm{mms}$. & Controlled \\
\hline
\end{tabular}

The reason for the observed parallelism between this phenomenon and poor control of the ocular tension is not clear. The formation of peripheral anterior synechiae has not been observed. The access to the angle can be gonioscopically observed to be narrowed, often to a mere chink, though the angle itself has remained open and of approximately the same apparent depth. Intermittent angle closure may occur, leading to trabecular damage and impaired outflow. A type of mioticinduced "mixed glaucoma" may thus account for some cases (Abrams, 1961). Alternatively, closure of the angle by contact alone may be responsible (Foulds and Phillips, 1957). It is interesting to note in this connexion that one case in which the tension was not adequately controlled became well controlled on P.I. when the (cataractous) lens was extracted.

\section{(3) Tonography}

In those cases in which little or no improvement in outflow was observed in the presence of a fairly well controlled tension, the possible inference is that P.I. lowered the tension by diminishing aqueous secretion. Conversely, in the presence of the very shallow-looking anterior chamber presented by many of the "imperfectly controlled" group, outflow may have been impeded by the weight of the tonometer during tonography. Becker and Shaffer (1961), however, postulate that the pressure of the tonometer on the cornea during tonography increases facility of outflow; in the presence of a bowed-forward iris, it is conceivable that the contrary may occur, mechanical indentation and depression of the cornea leading to further obstruction of access to the angle. 


\section{(4) Use of a Weak Mydriatic}

This was attempted in six eyes with axial lens opacity. Ephedrine drops 1 per cent., phenylephrine drops 5 and 10 per cent., and homatropine drops 0.5 per cent., once a day were tried, but produced little or no mydriasis. Homatropine drops 1 per cent. once a day gave better results. In one case in which, in addition, iris cysts had developed in both eyes, the pupils dilated from 1.0-1.5 mm. to $2.0-2.5 \mathrm{~mm}$., and the cysts, which had been seen to impede axial light rays, became flattened and not obtrusive. Associated with this mydriasis, both anterior chambers became appreciably deeper. In another case, the visual improvement was considerable but, with increasing bowing forward of the iris, it was used with some diffidence, and in fact it shortly became evident that control was not being kept up; stopping the mydriatic was once again associated with improvement of control.

\section{(5) Complications and Side-effects}

(a) One patient developed intolerance to the drug, with severe hyperaemia and pain in both eyes, associated with vomiting after 4 days on P.I. This necessitated stopping the drug.

(b) An acute attack of angle-closure developed in an eye with a deep anterior chamber but probably chronic (partial) closed-angle glaucoma. The anterior chamber during the attack was practically absent (the attack subsided on treatment with Diamox and a successful drainage operation was later performed).

(c) Iris cysts occurred in both eyes in one patient and in one eye in another.

(d) No other side-effects, local or systemic, were noted, apart from slight ocular discomfort on starting treatment (which invariably passed off with continued administration of P.I.), and some hyperaemia, which is a common occurrence.

\section{Summary}

A report is presented of a trial of phospholine iodide (P.I.) on a group of 21 patients (36 eyes).

A marked fall in intra-ocular pressure ( 8 to $15-20 \mathrm{~mm}$. $\mathrm{Hg}$ lower than on previous therapy) occurred in 29 eyes initially (approximately 80 per cent.). After 6 months of treatment, control was still maintained in 72.2 per cent. of cases, but after 14 months of follow-up, $38 \cdot 8$ per cent. were controlled and 25 per cent. imperfectly controlled, $36 \cdot 1$ per cent. being failures.

In the phakic cases, a common observation, as treatment progressed, was the appearance of iris bombé (62.5 per cent. of cases). Those cases that presented an unchanged appearance of the anterior chamber (only ten eyes in the series) showed an 80 per cent. figure of successful control after 14 months, whereas those eyes presenting an appearance of iris bombé showed 65 per cent. of failures or imperfect control. The reason for this is not known. Peripheral anterior synechiae have not been observed to form.

A discrepancy occurred in several cases between the tonographic studies and the level of intra-ocular pressure, poor outflow being associated with fairly good levels of intra-ocular pressure. The explanation of this is also not clear. 
A discussion of the concomitant use of a mydriatic and of the complications and side-effects encountered is presented.

Our thanks are due to Mr. Redmond Smith for his helpful criticism and advice concerning this paper. We are indebted to Messrs. Samoore Ltd., distributors of phospholine iodide in the United Kingdom, for supplies of the drug.

Abrams, J. D. (1961). Brit. J. Ophthal., 45, 503.

\section{REFERENCES}

American Medical Association (1961). Council on Drugs: "New and Non-official Drugs". Lippincott, Philadelphia.

Barkan, O. (1954). Amer. J. Ophthal., 37, 332.

BeCKer, B., and GAGE, T. (1960). A.M.A. Arch. Ophthal., 63, 102. , Pyle, C. C., and Drews, R. C. (1959). Amer. J. Ophthal., 47, 635. and ShafFer, R. N. (1961). "Diagnosis and Therapy of the Glaucomas". Mosby, St. Louis.

Drance, S. M. (1959). Trans. Canad. ophthal. Soc., 21 and 22, 84. (1960). Trans. ophthal. Soc. U.K., 80, 387. and CARR, F. (1960). Amer. J. Ophthal., 49, 470.

Foulds, W. S., and Phillips, C. I. (1957). Brit. J. Ophthal., 41, 208.

Giardini, A., and Paliaga, G. P. (1959). Boll. Ocul., 38, 683.

Grant, M. W. (1962). "Toxicology of the Eye", p. 368. Thomas, Springfield, Ill.

Gray, L. F., and Robinson, J. P. (1960). Amer.J. Ophthal., 49, 1162.

Holmberg, A. (1962). Report read at meeting of the Swedish Ophthalmological Association, June 2, 1962.

LAWLOR, R. C., and LeE, P. (1960). Amer. J. Ophthal., 49, 808.

LeOPOLD, I. H., Gold, P., and Gold, D. (1957). A.M.A. Arch. Ophthal., 58, 363.

LloYd, J. P. F. (1963). Brit. J. Ophthal., 47, 469.

MAMo, J. G., and LeOPold, I. H. (1958). Amer. J. Ophthal., 46, 724.

SchaumanN, W., and Job, C. (1958). J. Pharmacol. exp. Ther., 123, 114.

SugAR, H. S. (1951). "The Glaucomas", p. 143. Mosby, St. Louis.

SWAN, K. C. (1959). In "Symposium of Glaucoma", ed. William B. Clark, p. 159. Mosby, St. Louis. 